\title{
Laws of Arbitration in Nepal
}

\author{
Shuvan Raj Acharya \\ Lecturer, Nepal Commerce Campus
}

\section{Background of the study}

The history of laws and experiences of arbitration has not so long in context of Nepal. Arbitration is one of the most important methods of Alternative Dispute Resolution (ADR) in commercial sector. There are various ways to settle the disputes through out of the Courts; i.e. arbitration, mediation, negotiation conciliation, trial, mini-trial, med-arb, concilio-arb, etc. In this modern business age, arbitration is becoming famous.

The formal legal history of arbitration law in Nepal dates back to the year $1957 \mathrm{AD}$. When the amendment made in the Act inserted a provision of arbitration in the case where the development board is involved with. After introducing arbitration by giving room in the Act, a trend has been established to recognize arbitration as a means of settling disputes in other Acts subsequently. Such Acts binding the system the system for settling disputes via arbitration are Nepal Airlines Act, 1962 AD, Commercial Act, 1974 AD and so on. (Karki, 2015) Before promulgating the special law relating to arbitration, Nepal has been stated the scattered legal provisions in relation to the settlement of disputes through method of ADR, i.e.; arbitration and mediation in several Acts.

The Nepalese Arbitration Law acquired the precise and formal recognition of lawmakers in $1981 \mathrm{AD}$ through the enactment of the Arbitration Act, $1981 \mathrm{AD}$. It was the Act which was wholly concentrated with the arbitration. After being existed for approximately 18 years, now the Act has been replaced by Arbitration Act, 1999 AD., which is the prevailing law of Nepal to this effect. The Act, which has been brought in practice since 15th April 1999 AD(karki, 2015).

\section{Conceptual framework}

Arbitration is a more formalized process resulting in a binding award that will be enforced by courts of law in many countries. (Richard, 2009), Arbitration is a normal process where dispute emerged between parties is resolved outside the established court by the legally appointed person or an institution under the consensus of the parties. (Bhandari, 2016), Arbitration is a means of settling disputes otherwise than by court action and it arises when one or more persons are appointed to hear the arguments submitted by the parties and to give decision on them. (Marsh S.B., 1995), When dispute arises during the progress of a contract it is not necessary that it should automatically go before a court of law for resolution. The parties involved may agree 
to submit their differences to a third party in whom they have confidence and whose decision they will accept and enforce. To resolve a dispute in this manner, without recourse to the courts, is the essence of arbitration. (Lawson, 1997), Therefore, Arbitration is a means or technique or method or way or manner or mechanism to resolve the commercial type of disputes by neutral expert called arbitrator out of the courts.

Arbitration Act, 1999 has not defined the word arbitration but it has defines 'agreement' means a written agreement reached between the concerned parties for a settlement by arbitration of any dispute relating to any specific legal issue that has arise nor may arise in the future as under a contract or not. (Section 2a of Arbitration Act, 1999), Where two or more persons agree that a dispute or potential dispute between them shall be decided in a legally binding way by one or more impartial persons in a judicial manner, that is upon evidence put before him or them, the agreement is called an arbitration agreement or a submission to arbitration. When, after a dispute has arisen, it is put before such person or persons for decision, the procedure is called arbitration, and the decision when made is called an award. (Ronald, 1987)

The Arbitration Act, 1999 has defined other important terminologies which are used in the process of arbitration, i.e.; District and High Court, dispute, counter claim, rejoinder, arbitrator, and matters referred to arbitration, appointment and disqualification of arbitrators, office, rules and language to be used in arbitration, provisions relating to rights and duties of arbitrator; etc.

\section{Who is arbitrator?}

Arbitrator means an arbitrator appointed for the settlement of the dispute and the term includes a panel of arbitrators. (Section 2h of Arbitration Act, 1999) The number of arbitrator should be odd and normally, 3 but 1 is also allowed where the parties determine so. In connection with the appointment of arbitrator by the parties or the court has been recognized by the Act. (Section 5-8) An arbitrator's authority can be revoked, and his position could be made vacant. To act improperly, lacking of qualification are some grounds on which authority or arbitrator can be revoked. (Section 11) The arbitrator has to take oath and has to hold essential qualification under law and agreement. The qualification of law is to have contractual capacity, not to be punished under law on criminal charges, not to be insolvent, etc. (Section 9-10) The Act has stated the rights and duties of arbitrator. Some of the rights are to have submission, determine the jurisdiction and procedure, to fix the venue, to seek the assistance of the court, to issue different kinds of award and the like. Similarly, some of the duties are to be fair, impartial, to respect the principle of natural justice, to take oath etc. (Section 21 )

\section{Disputes to be settled through arbitration}

In case any agreement provides for the settlement of disputes through arbitration, the disputes related with that agreement or with issues coming under that agreement shall be settled through arbitration according to the procedure specified in that 
agreement, if any, and if not, according to the Act. In case of concerned parties to a civil case of a commercial nature which has been filed in a court and which may be settled through arbitration according to existing laws, file an application for its settlement through arbitration. (Section 3) The Act has prohibited referring non-arbitral issues to arbitration.

\section{Procedures of arbitration}

The arbitrator must hold the office immediately after his appointment or submission of dispute in case where he is named in the agreement. He needs to provide opportunity of claim, counter claim, rejoinder and hearing of the case by the lawyer; if appointed, and to the parties themselves for discussion, if the lawyer is not appointed. His award must be based on evidence. The arbitrator has to follow the law as mentioned in the agreement, if not mentioned they must follows Nepalese law as the substantive law. The arbitrator can also exercise the discretionary power, if the parties have given such power. He provides award on the basis of terms and conditions as under the contract and also considers the commercial usages related with the case and hearing should be held in cameras unless otherwise agreed. (Section 17) Any notice to be issued in relation with arbitration, or any notice or summon to be notified in the name of any party residing within or outside the country in relation with the hearing by the arbitrator. He must deliver notice to the concerned parties by tele-fax or telegram or any other media. (Section 20)

\section{The award}

The award must be delivered within 120 days from the date of submission of application. (Section 24) The majority decision of the umpire is recognized as valid in case where different opinions arise between the parties. The award must be signed by all the arbitrators and read out as well as supplied to the parties. The dissenting opinion is also allowed. The award may include matters such as description of dispute; decision date etc. (Section 26-27) If the party dissatisfied with the award is given by the arbitrator can be challenged in the High Court for invalidating it within 35 days from the date of receipt of award. (Section 25)

\section{Remuneration of arbitrator}

The parties shall be paid the fees which have been fixed by the arbitrators with the consultation of parties to the proceedings. Similarly, the remuneration of the arbitrator is also regulated by the agreement, if not, the fees is fixed by the arbitrators by considering the circumstances and by discussing with parties. (Section 36) The parties shall be paid the fees as a full payment or in the form of advance payment as ordered by the arbitrator.

\section{Execution of award}

The execution must be made within 45 days from the date of issuance of award. If the award is not executed within 45 days, the concerning party may apply to the 
District Court within 30 days from the expiry of time limit specified. (Section 31-32) An award made abroad can be executed in Nepal. If any party wishes to have award made in a foreign country enforced in Nepal, he has to submit an application to the High Court. The party who wants to execute the foreign arbitral award in Nepal, he has to apply in High Court. The award cannot be executed in case of the award is not made as per the law of Nepal and the award is against the public policy. (Section 34)

\section{Conclusion}

The present Arbitration Act has helped business community by stating proper legal provisions. Because of this, the Act can be regarded as a good law but it is not sufficient in the present context of e-commerce. However, the Act is silent on definition of arbitration, who can file claim for the arbitration, what types of matter are to be referred to arbitration, duties and liabilities of arbitrator or umpire, the Act seems insufficient to define the non-arbitral disputes. Similarly, the arbitration process is more formalized, short, cost effective, faster, simplicity, convenience; privacy, more efficient, final and binding award etc. are in principally a mechanism of alternative dispute resolution, in practice it is not. The appropriate amendment of such lacking will prove the Act successful.

The alternative methods include a number of procedures that permit parties to settle their disputes out of the courts with the help of a neutral person of their choices. Being a member of United Nations Organization, World trade Organization and other International Organizations, Nepal has approved various international standards. Nepal has accepted the UNCITRAL Model Law and also endorsed the Convention on the Recognition \& Enforcement of Foreign Arbitral Awards-the New York Convention, 1958. Nepal has also enacted \& amended some of the domestic laws in line with the international legal standards, i.e. Contract Act, Company Act, Foreign Investment \& Technology Transfer Act, Industrial Enterprises Act, Competition Act, Labor Act, and Securities Act, Banking laws so on.

\section{References}

Arbitration Act, 1999.

Bhadari, D. R. (2016) Business Law, ABC Books publishers \& Distributers House pvt. Ltd., Kathmandu. Bernstien, R. (1987), Hand Book of Arbitration Practice, Sweet \& Maxwell Limited, London.

Karki, S.B., Mishra, B.P. \& Parajuli, D.N. (2015). Business Law, Platinum Publication Pvt. Ltd Kathmandu.

Lawson, R. (1997), Business Law, Butterworth-Heinemann, Oxford, Great Britain.

Marsh, S.B. (1995), Business Law, Stanley Thornes Publishers Ltd., United Kingdom.

Schaffer, R. (2009), International Business law and its Environment, South-Western Cengage learning, United States of America. 